Bull. Fac. Agric. Cairo Univ. 61: 251-262 (2010).

\title{
RESPONSE OF Stevia rebaudiana Bertoni TO FOLIAR APPLICATION OF GA 3 AND IBA 1. Morphological and yield traits
}

(Reseived:3.4.2010)

\author{
By \\ G. A. El-Nagdy, F. A. Yossef, A. E. Attia * and A. M. Salama \\ Department of Agricultural Botany, Faculty of Agriculture, Cairo University, Giza, Egypt \\ *Sugar Crops Research Institute, Agricultural Research Center, Giza, Egypt
}

\begin{abstract}
The field experiment was carried out during the two successive seasons 2007/08 and 2008/09 aiming to investigate all the factors that may affect the morphological traits of stevia plants; Stevia rebaudiana Bertoni. Two different types of growth regulators; $\mathrm{GA}_{3}$ and IBA with three concentrations 0,250 and $500 \mathrm{ppm}$, in addition to two sprays. The most remarkable results could be summarized, with regard to the adopted concentrations or number of sprays, $\mathrm{GA}_{3}$ treatments generally caused elevation in the averages of plant height and the number of branches per plant as compared with IBA treatments. Plants received two sprays regardless of the type of the used growth regulators (GR's) or the used concentration were the tallest and more branched. In addition, a positive relationship could be established between averages of plant height and the number of branches per plant and the adopted concentration. The interaction between the three studied factors proved that the double spray treatment by $\mathrm{GA}_{3}$ with $500 \mathrm{ppm}$ showed a remarkable elevation in the mean values of all studied morphological and yield characters.
\end{abstract}

Key words: $G A_{3}, I B A$, morphology, Stevia rebaudiana, yield.

\section{INTRODUCTION}

Stevia rebaudiana Bertoni is a herbaceous perennial, normally used as a natural herbal sweetener and commonly known as honey leaf. It is one of 154 species of the genus Stevia which belongs to family Asteraceae (Compositae). All are distributed in the New World, from the Southwestern United States to the Northern Argentine and became known by the Europeans due to its discovery by Antonio Bertoni in 1887 (David and Rank, 2002). Commercially the plant and its extracts are also used as a diet programme. The plant is also used to treat diabetes, hypoglycemia, candidacies, high blood pressure, skin abrasions and to inhibit the growth and reproduction of certain bacteria-like plaque. The greatest economic potential of stevia is its use as a natural alternative to artificial sweeteners (such as aspartame or sodium saccharin).

Stevia was introduced to Egypt in 1990 as a source of natural sweet product for low energy foods. Stevia has many advantages to be used in
Egypt since it succeeds in poor lands with moderate water and fertilizer requirements plus its high potential for yield under warm climates. The necessary steps to expand stevia cultivation in Egypt are the development of seeds, care of seedlings and appropriate agri-practices, including information on optimized crop inputs. Understanding of the biology and agricultural practices of stevia are prerequisites for the adoption and successful cultivation of stevia to be a new economic cultivated crop in Egypt, (Attya, 2005).

Gibberellin enhancement of stem elongation in intact plant usually involves increase in both cell numbers and cell length. Studies employing GAresponsive genetic dwarfs (Basford, 1961and Loy and Liu, 1974), plants treated with growth retardants (Sachs and Kofranek, 1963) and rosette plants (Bernier et al., 1964), proved convincing evidence that stimulation of cell division in the sub-apical meristematic zone is a common feature of gibberellins mediated increase in stem elongation. IBA has been identified in a number of plant species 
from maize (Zea mays) and pea (Pisum sativum) to (Arabidopsis thaliana) and concentrations of free IBA approach the levels of free IAA in a number of plants IBA, like IAA, is also found in conjugated forms, yet at significantly lower levels than IAA. (Ludwig-Muller et al., 1993) IBA is the preferred auxin for the induction of root formation because it is much more potent than IAA or synthetic auxins (Ludwig-Muller, 2000).

This work was carried out to investigate the effect of different concentrations of growth regulators; Gibberellic acid $\left(\mathrm{GA}_{3}\right)$ and Indole Butyric Acid (IBA) and the number of sprays as well as the different concentrations on some morphological and agronomic characters of stevia plants.

\section{MATERIALS AND METHODS}

The field experiment was carried out during the two successive seasons 2007/08 and 2008/09 in Agricultural Research Station, Agricultural Research Center, Giza Governorate to study the effects of one and two sprays, (30 days interval after cutting), two different types of growth regulators $\left(\mathrm{GA}_{3}\right.$ and IBA) and three adopted concentrations; 0, 250 and $500 \mathrm{ppm}$ on the plant morphology and plant productivity. The used plant material was terminal cuttings $15 \mathrm{~cm}$ long secured from Sugar Crops Research Institute. Growth regulator treatments were sprayed early in the morning, till dripping. The following characters were studied; plant height $(\mathrm{cm}$.$) , number of branches per plant and total leaves$ dry weight (g.). The yield of dry leaves was estimated by weighing air dried leaves kept in the shade for 5 days. The cutting date, plant age, season and the average day length for each of the four cuts during the experiment are presented in the following tabulation:-

The experiment layout was split split plot design with three replicates. The collected data were subjected to the convenient statistical analysis using the MSTATC (Anonymous, 1986) computer software.

\section{RESULTS AND DISCUSSION}

\subsection{Plant height}

Regardless of the cutting or seasonal effects; the single, double and triple interaction effects between the three studied factors will be discussed. It is evident from Table ( $1 \mathrm{a}, \mathrm{b}, \mathrm{c}, \mathrm{d}$ and e) that the three studied factors significantly affected the average plant height of the four cuttings in both seasons. However, significant effects were detected for the interactions between the factors under study.

\subsubsection{Main effects of the studied factors \\ 3.1.1.1. Number of sprays}

Table (1 a) shows that, the plants received two sprays regardless of the type of GR or the concentration, became the tallest as compared with the single spray. The highest values of plant height $\left(71.29\right.$ and $68.75 \mathrm{~cm}$.) were observed in the $4^{\text {th }}$ cut in the $1^{\text {st }}$ and $2^{\text {nd }}$ seasons as compared with the values of single spray $(65.72$ and $59.72 \mathrm{~cm}$.). Generally, in the $1^{\text {st }}$ season, the two sprays treatment caused increases in plant height as compared with the single were 5.9, 10.6, 20.7 and $7.8 \%$ for the four studied cuts, arranged in ascending order. This was also clear in the second season where the corresponding increase percentages in plant height were $12.4,14.6,10.2$ and $13.1 \%$ for the same cuttings, respectively. It is also noticed that, within each cut, the double sprays caused an increase in the average plant height, especially in the $1^{\text {st }}$ and $4^{\text {th }}$ cuts in both seasons.

\subsubsection{Type of growth regulator}

$\mathrm{GA}_{3}$ treatment generally caused remarkable elevation in the average plant height as compared with IBA treatment. In the $1^{\text {st }}$ season, $\mathrm{GA}_{3}$ increased the average plant height by $6.3,1.3,13.0$ and $10.0 \%$ for the four studied cuts as compared with the IBA

\begin{tabular}{|c|l|l|l|c|}
\hline Cut number & \multicolumn{1}{|c|}{ Cutting date } & \multicolumn{1}{|c|}{ Plant age } & \multicolumn{1}{c|}{ Season } & $\begin{array}{c}\text { Ave. day } \\
\text { length (hours) }\end{array}$ \\
\hline 1 & $25^{\text {th }}$ July & 90 days & Summer & 13.35 \\
2 & $25^{\text {th }}$ October & 180 days & Fall & 11.44 \\
3 & $25^{\text {th }}$ January & 270 days & Winter & 10.58 \\
4 & $25^{\text {th }}$ April & 360 days & Spring & 12.11 \\
\hline
\end{tabular}


arranged in ascending order (Table 1 a). The same trend was obtained in the second season where the corresponding increase percentages of plant height were $5.6,8.7,14.0$ and $11.8 \%$ for the same cuttings, respectively. It is also observed that, in both seasons within each cut, the $\mathrm{GA}_{3}$ treatment enhanced the average plant height especially in the case of the $1^{\text {st }}$ and $4^{\text {th }}$ cuts. The enhancement effect of $\mathrm{GA}_{3}$ on the average plant height is commonly reported by many workers (e.g Mander, 2003) who reported that, gibberellins are important plant growth hormones with agricultural applications and influence a wide range of physiological properties like germination, stem elongation and flowering.

\subsubsection{Adopted concentration}

Statistically, the plants treated with the highest concentration $(500 \mathrm{ppm})$ were taller than those treated with the lowest one $(0 \mathrm{ppm})$. Positive relationship was established between the average plant height and the used concentrations. Relative to the control, in the $1^{\text {st }}$ season, two sprays by $500 \mathrm{ppm}$ caused increases in plant height as compared with a single spray by $5.9,10.6,20.7$ and $7.8 \%$ for the four studied cuts arranged in ascending order, (Table, 1 a). These findings are in agreement with the results reported by Bhattachartee et al., (2000) and AbouBakr and El-Sgai (2001).

3.1.2. The interaction between the number of sprays and the used growth regulators

Data in Table $(1 \mathrm{~b})$ prove that, in both seasons, double sprays with $\mathrm{GA}_{3}$ were the most favorable treatment for enhancing the highest average plant height, as these averages, in the $1^{\text {st }}$ season were, $63.55,38.56,22.43$ and $73.83 \mathrm{~cm}$. for the four studied cuts arranged in ascending order. The corresponding recorded values for the second season were, $64.35,32.38,19.38$ and $74.33 \mathrm{~cm}$. Single spray with $\mathrm{GA}_{3}$ showed the same trend with high magnitude as compared with single or double spray with IBA. Relative to the single spray with $\mathrm{GA}_{3}$, the increased percentages due to double sprays were $4.3,21.3,3.2$ and $4.8 \%$ in the $1^{\text {st }}$ season and were $7.0,19.0,1.1$ and $15.4 \%$ in the $2^{\text {nd }}$ one for the four studied cuts, respectively. The interaction effects between the number of foliar applications of growth hormones were early reported by many investigators on different plant species (Ebad et al., 1990).

3.1.2.1. The interaction between the number of sprays and the used concentration

Regardless of the used growth regulators, the

Table ( 1 a): Main effects of the number of sprays, types of GR and the adopted concentration on the average stevia plant height in 2007-08 and 2008-09 seasons

\begin{tabular}{|c|c|c|c|c|c|c|c|c|c|}
\hline \multirow{2}{*}{\multicolumn{2}{|c|}{ Treatments }} & \multicolumn{4}{|c|}{$2007-08$} & \multicolumn{4}{|c|}{ 2008-09 } \\
\hline & & $1^{s t} \mathrm{cut}$ & $2^{\text {nd }}$ cut & $3^{\text {rd }}$ cut & $4^{\text {th }}$ cut & $1^{s t} \mathrm{cut}$ & $2^{\text {nd }}$ cut & $3^{\text {rd }}$ cut & $4^{\text {th }} \mathrm{cut}$ \\
\hline \multirow{2}{*}{$\begin{array}{l}\text { Number of } \\
\text { sprays }\end{array}$} & One spray & 59.39 & 35.77 & 19.64 & 65.72 & 52.61 & 27.17 & 17.81 & 59.72 \\
\hline & Two sprays & 63.11 & 40.03 & 24.77 & 71.29 & 60.09 & 31.82 & 19.83 & 68.75 \\
\hline \multicolumn{2}{|c|}{ L.S.D at 0.05} & 2.90 & 1.749 & 2.10 & 4.36 & 1.823 & 2.20 & 1.50 & 3.55 \\
\hline \multirow{2}{*}{$\begin{array}{l}\text { Growth } \\
\text { regulator }\end{array}$} & $\mathbf{G A}_{\mathbf{3}}$ & 62.24 & 38.16 & 21.08 & 72.14 & 57.99 & 29.79 & 19.17 & 69.36 \\
\hline & IBA & 58.26 & 37.64 & 18.33 & 64.88 & 54.71 & 27.19 & 16.47 & 61.11 \\
\hline \multicolumn{2}{|c|}{ L.S.D at 0.05} & 1.49 & 0.24 & 0.73 & 1.23 & 1.73 & 2.23 & 1.53 & 0.64 \\
\hline \multirow{3}{*}{$\begin{array}{l}\text { Concentration } \\
\text { of growth } \\
\text { regulator }\end{array}$} & O ppm & 54.78 & 35.86 & 17.42 & 65.00 & 52.68 & 24.71 & 16.50 & 61.54 \\
\hline & $250 \mathrm{ppm}$ & 61.08 & 37.72 & 19.76 & 66.99 & 55.47 & 27.62 & 17.17 & 63.37 \\
\hline & $500 \mathrm{ppm}$ & 64.89 & 40.11 & 21.94 & 73.54 & 60.89 & 33.15 & 19.79 & 67.79 \\
\hline \multicolumn{2}{|c|}{ L.S.D at 0.05} & 1.97 & 1.26 & 0.84 & 1.40 & 1.55 & 2.53 & 1.58 & 2.01 \\
\hline
\end{tabular}

Table (1 b): Effect of interaction between the number of sprays and growth regulators on the average plant height of stevia plant in 2007-08 and 2008-09 seasons.

\begin{tabular}{|c|c|c|c|c|c|c|c|c|c|}
\hline \multicolumn{2}{|c|}{ Treatments } & \multicolumn{4}{|c|}{ 2007-08 } & \multicolumn{4}{|c|}{ 2008-09 } \\
\hline $\begin{array}{c}\text { Number of } \\
\text { sprays }\end{array}$ & $\begin{array}{l}\text { Growth } \\
\text { regulator }\end{array}$ & $1^{s t}$ cut & $2^{\text {nd }}$ cut & $3^{\text {rd }}$ cut & $4^{\text {th }}$ cut & $1^{s t}$ cut & $2^{\text {nd }}$ cut & $3^{r d}$ cut & $4^{\text {th }}$ cut \\
\hline \multirow{2}{*}{ One spray } & $\mathbf{G A}_{3}$ & 60.93 & 31.78 & 21.73 & 70.45 & 60.16 & 27.56 & 19.17 & 64.39 \\
\hline & IBA & 57.85 & 25.76 & 19.56 & 61.00 & 52.39 & 26.78 & 16.44 & 55.06 \\
\hline \multirow{2}{*}{$\begin{array}{c}\text { Two } \\
\text { sprays }\end{array}$} & $\mathbf{G A}_{3}$ & 63.56 & 38.56 & 22.43 & 73.83 & 64.35 & 32.81 & 19.38 & 74.33 \\
\hline & IBA & 58.67 & 30.50 & 17.11 & 68.76 & 55.83 & 26.83 & 16.50 & 63.17 \\
\hline \multicolumn{2}{|c|}{ L.S.D at 0.05} & 1.36 & 1.48 & 1.03 & 1.74 & 2.45 & 3.15 & 1.23 & 0.91 \\
\hline
\end{tabular}


interaction between the number of sprays and the adopted concentration, significantly affected the regulators and the concentration used

Data presented in Table $(1 \mathrm{~d})$ reveal that in both

Table (1 c): Effect of interaction between the number of sprays and the concentration of growth regulator on the stevia plant height in 2007-08 and 2008-09 seasons

\begin{tabular}{|c|c|c|c|c|c|c|c|c|c|}
\hline \multicolumn{2}{|c|}{ Treatments } & \multicolumn{4}{|c|}{ 2007-08 } & \multicolumn{4}{|c|}{ 2008-09 } \\
\hline $\begin{array}{l}\text { Number of } \\
\text { sprays }\end{array}$ & Concentration & $1^{s t}$ cut & $2^{\text {nd }} \mathrm{cut}$ & $3^{r d}$ cut & $4^{\text {th }} \mathrm{cut}$ & $1^{\text {st }}$ cut & $2^{\text {nd }} \mathrm{cut}$ & $3^{r d}$ cut & $4^{\text {th }} \mathrm{cut}$ \\
\hline \multirow{3}{*}{ One spray } & 0 ppm & 54.78 & 32.89 & 17.17 & 61.17 & 48.67 & 23.58 & 16.42 & 56.83 \\
\hline & 250 ppm & 60.94 & 34.92 & 18.92 & 64.70 & 52.00 & 26.42 & 18.17 & 59.25 \\
\hline & $500 \mathrm{ppm}$ & 63.44 & 39.50 & 21.85 & 71.30 & 57.17 & 31.50 & 18.83 & 66.25 \\
\hline \multirow{3}{*}{$\begin{array}{c}\text { Two } \\
\text { sprays }\end{array}$} & 0 ppm & 55.78 & 34.93 & 16.67 & 63.03 & 47.20 & 24.83 & 16.58 & 58.08 \\
\hline & 250 ppm & 61.22 & 40.53 & 20.61 & 69.27 & 58.95 & 28.83 & 17.37 & 67.50 \\
\hline & 500 ppm & 66.33 & 41.72 & 22.03 & 75.78 & 64.62 & 34.80 & 20.75 & 72.50 \\
\hline \multicolumn{2}{|c|}{ L.S.D at 0.05} & 1.19 & 1.78 & 1.18 & 1.98 & 1.48 & 1.10 & 0.37 & 2.84 \\
\hline
\end{tabular}

average plant height (Table $1 \mathrm{c})$. It is evident that zero concentration (control) showed the shortest plants either with single or double sprays. However, $250 \mathrm{ppm}$ concentration significantly enhanced the average plant height. While, the plants treated with the highest concentration $500 \mathrm{ppm}$ were taller than those treated with $250 \mathrm{ppm}$. Positive relationship could be established between the used concentration and plant height, as the adopted concentration was higher the plant height increased. Relative to the control, in the $1^{\text {st }}$ season, two spray treatments with $500 \mathrm{ppm}$ caused the highest plant height as compared with single spray treatments. The average increased percentages due to double sprays with 500 ppm were 18.9, 19.4, 32.1 and $20.2 \%$ for the four studied cuts arranged in ascending order, respectively. The corresponding increased percentages in the second season were $36.9,40.1$, 25.1 and $24.8 \%$. The same trend was obtained but with less percentage in the case of single spray with the same adopted concentration (500 ppm).

3.1.2.2. The interaction between the used growth seasons, $\mathrm{GA}_{3}$ treatments with 500 ppm concentration was the most favorable treatment for enhancing the plant height, as the average recorded values in the $1^{\text {st }}$ season were 66.0, 41.9, 23.18 and $76.83 \mathrm{~cm}$ for the four studied cuts arranged in ascending order. The corresponding recorded values for the second season were 61.83, 34.22, 20.67 and $74.83 \mathrm{~cm}$ for the same cuts arranged in the same order. Positive relationship could be established between plant height and the used $\mathrm{GA}_{3}$ concentration. IBA treatments showed same trend when used with any adopted concentrations 0,250 and $500 \mathrm{ppm}$. The highest used $500 \mathrm{ppm}$ concentration of IBA showed remarkable increase in the average plant height as, compared extent to $\mathrm{GA}_{3}$. 3.1.2.3. The interaction between the used growth regulators, the used concentration and number of sprays

Data presented in Table ( 1 e) show that the triple interaction between these factors was significant in both seasons and with all studied cuts. The highest recorded plant height was associated with double

Table (1 d): Effect of the interaction between growth regulators and the adopted concentration on stevia plant height in 2007-08 and 2008-09 seasons.

\begin{tabular}{|c|c|c|c|c|c|c|c|c|c|}
\hline \multicolumn{2}{|c|}{ Treatments } & \multicolumn{4}{|c|}{ 2007-08 } & \multicolumn{4}{|c|}{ 2008-09 } \\
\hline $\begin{array}{l}\text { Growth } \\
\text { regulator }\end{array}$ & Concentration & $1^{\text {st }}$ cut & $2^{\text {nd }}$ cut & $3^{\text {rd }}$ cut & $4^{\text {th }}$ cut & $1^{s t}$ cut & $2^{\text {nd }} \mathrm{cut}$ & $3^{r d}$ cut & $4^{\text {th }}$ cut \\
\hline \multirow[b]{3}{*}{$\mathbf{G} \mathbf{A}_{3}$} & 0 ppm & 57.5 & 35.55 & 18.42 & 67.75 & 55.5 & 26.42 & 16.33 & 65.17 \\
\hline & 250 ppm & 63.22 & 39.03 & 21.65 & 71.84 & 58.53 & 28.75 & 18.50 & 68.08 \\
\hline & 500 ppm & 66.00 & 41.90 & 23.18 & 76.83 & 61.83 & 34.22 & 20.67 & 74.83 \\
\hline \multirow[b]{3}{*}{ IBA } & 0 ppm & 55.06 & 36.17 & 16.42 & 61.25 & 50.87 & 24.80 & 14.67 & 55.02 \\
\hline & $250 \mathrm{ppm}$ & 58.94 & 37.42 & 17.88 & 62.13 & 52.42 & 26.50 & 15.83 & 58.67 \\
\hline & 500 ppm & 61.78 & 39.33 & 20.00 & 68.50 & 56.95 & 29.14 & 17.10 & 60.75 \\
\hline \multicolumn{2}{|c|}{ L.S.D at 0.05} & 1.29 & 0.48 & 0.51 & 1.98 & 2.2 & 0.71 & 0.47 & 2.84 \\
\hline
\end{tabular}


sprays by $500 \mathrm{ppm} \mathrm{GA}_{3}$ treatment.

This treatment proved to be the most reliable one to achieve the tallest stevia plants. Regardless of the seasons and the cutting effects, the used triple treatments could be ranked according to its enhancement effect on the average stevia plant height as follows; double sprays by $\mathrm{GA}_{3} 500 \mathrm{ppm}$ $(29.2 \%)$ followed by single spray $\mathrm{GA}_{3} 500 \mathrm{ppm}$ $(22.6 \%)$, double sprays by $\mathrm{GA}_{3} 250 \mathrm{ppm}(17.8 \%)$ then single spray by $\mathrm{GA}_{3} 250 \mathrm{ppm}(11.4 \%)$. IBA treatment showed the same trend with very low magnitude as compared with $\mathrm{GA}_{3}$.

\subsection{Number of branches per plant}

\subsubsection{Main effects of the studied factors}

\subsubsection{Number of sprays}

It is clear from Table ( 2 a) that, the main effect of the number of sprays was significant in both seasons in all cuts. The double sprays led to the highest number of branches/plant as compared with
The adopted $\mathrm{GA}_{3}$ application was more likely to increase the number of branches/plant than IBA application (Table 2 a). Therefore, the increase in the number of branches/ plant by using $\mathrm{GA}_{3}$ was suggested to be the result of increased Stem Apical Meristem (SAM) volume, which is mainly brought from the promotion of the cell division of the pith meristem and peripheral meristem in SAM. It is known that gibberellic acid promotes the longitudinal growth due to both cell elongation and cell division. The increased number of branches has been reported to be positively related to the diameter of SAM (Yamagishi, 1992). He also pointed out that there was a close correlation between the number of branches and the diameter of SAM. El-Shaarawy et al. (1982) on roselle plants suggested that $\mathrm{GA}_{3}$ treatments increased the average number of branches and this was in accordance with the present findings. On the contrary Sakr and El Kady

Table ( 1 e): Effect of the interaction between number of sprays, growth regulator and the adopted concentration on stevia plant height in 2007-08 and 2008-09 seasons.

\begin{tabular}{|c|c|c|c|c|c|c|c|c|c|c|}
\hline \multicolumn{3}{|c|}{ Treatments } & \multicolumn{4}{|c|}{ 2007-08 } & \multicolumn{4}{|c|}{ 2008-09 } \\
\hline $\begin{array}{c}\text { Number of } \\
\text { sprays }\end{array}$ & $\begin{array}{l}\text { Growth } \\
\text { regulator }\end{array}$ & Concentration & $1^{s t} \mathrm{cut}$ & $2^{\text {nd }} \mathrm{cut}$ & $3^{r d}$ cut & $4^{\text {th }}$ cut & $1^{s t}$ cut & $2^{\text {nd }}$ cut & $3^{r d}$ cut & $4^{\text {th }}$ cut \\
\hline \multirow{6}{*}{ One spray } & \multirow{3}{*}{$\mathbf{G} \mathbf{A}_{3}$} & 0 ppm & 58.89 & 32.11 & 17.42 & 54.83 & 55.00 & 22.00 & 16.67 & 60.67 \\
\hline & & 250 ppm & 61.44 & 34.83 & 20.42 & 69.40 & 55.50 & 27.33 & 19.50 & 61.50 \\
\hline & & 500 ppm & 64.44 & 40.34 & 21.36 & 76.55 & 57.33 & 33.33 & 20.33 & 71.00 \\
\hline & \multirow{3}{*}{ IBA } & 0 ppm & 58.67 & 33.67 & 18.92 & 57.50 & 52.33 & 25.17 & 14.77 & 57.00 \\
\hline & & 250 ppm & 60.45 & 35.00 & 17.42 & 60.00 & 55.50 & 25.50 & 16.83 & 58.00 \\
\hline & & 500 ppm & 62.44 & 38.67 & 22.33 & 65.50 & 57.00 & 29.67 & 18.33 & 55.17 \\
\hline \multirow{6}{*}{$\begin{array}{c}\text { Two } \\
\text { sprays }\end{array}$} & \multirow{3}{*}{$\mathbf{G} \mathbf{A}_{3}$} & 0 ppm & 56.11 & 36.00 & 19.42 & 56.67 & 57.40 & 27.67 & 16.00 & 60.67 \\
\hline & & 250 ppm & 65.00 & 41.23 & 22.88 & 75.00 & 56.33 & 32.00 & 17.50 & 74.67 \\
\hline & & 500 ppm & 69.56 & 41.44 & 25.00 & 77.11 & 66.33 & 38.77 & 22.00 & 78.67 \\
\hline & \multirow{3}{*}{ IBA } & 0 ppm & 55.45 & 36.67 & 15.92 & 57.00 & 56.00 & 22.00 & 15.17 & 62.83 \\
\hline & & 250 ppm & 57.44 & 39.83 & 18.34 & 64.27 & 61.57 & 25.67 & 14.83 & 66.33 \\
\hline & & 500 ppm & 63.11 & 40.00 & 19.07 & 74.28 & 62.90 & 30.83 & 19.50 & 69.33 \\
\hline \multicolumn{3}{|c|}{ L.S.D. 0.05} & 3.93 & 2.01 & 1.67 & 2.80 & 3.11 & 1.94 & 1.82 & 4.01 \\
\hline
\end{tabular}

the single spray. In both seasons, the highest numbers of branches/plant were recorded in the first and fourth cuts. The average increased percentages in the number of branches per plant due to the number of sprays, regardless of the cutting, were 15.3 and $17.1 \%$ for the first and second seasons, respectively. This result is reflecting the role of the number of sprays on promoting the vegetative growth including branching. Moreover, the highest number of branches/ plant found in the fourth cut (spring cut), was due to the high number of sprouts emerging from under the ground in the spring time giving high numbers of new branches/ plant.

\subsubsection{Type of growth regulator}

(1981) reported that $\mathrm{GA}_{3}$ treatments did not affect the total number of branches in faba bean plants.

\subsubsection{Adopted concentrations}

It is obvious from Table (2 a) that in both seasons and all cuts, the number of branches per plant was increased with increasing the used concentrations from 0 to $500 \mathrm{ppm}$. Direct positive relationship could be established between the used concentration and the number of branches/plant. Relative to the control and regardless of the cuttings, the average increased percentages in the number of branches per plant due to $250 \mathrm{ppm}$ treatment were 20.1 and $14.6 \%$ for the $1^{\text {st }}$ and $2^{\text {nd }}$ seasons, respectively. However, for $500 \mathrm{ppm}$, the 
Table ( 2 a): Main effect of the number of sprays, growth regulators and the adopted concentrations on the number of branches / stevia plant in 2007-08 and 2008-09 seasons.

\begin{tabular}{|c|c|c|c|c|c|c|c|c|c|}
\hline \multirow{2}{*}{\multicolumn{2}{|c|}{ Treatments }} & \multicolumn{4}{|c|}{ 2007-08 } & \multicolumn{4}{|c|}{ 2008-09 } \\
\hline & & $1^{\text {st }}$ cut & $2^{\text {nd }}$ cut & $3^{\text {rd }}$ cut & $4^{\text {th }}$ cut & $1^{s t} \mathrm{cut}$ & $2^{\text {nd }}$ cut & $3^{\text {rd }}$ cut & $4^{\text {th }}$ cut \\
\hline \multirow{2}{*}{$\begin{array}{c}\text { Number of } \\
\text { sprays }\end{array}$} & One spray & 19.70 & 5.72 & 9.69 & 16.45 & 20.17 & 9.33 & 10.33 & 22.83 \\
\hline & Two sprays & 22.74 & 7.45 & 12.10 & 17.18 & 21.88 & 11.89 & 12.83 & 26.78 \\
\hline \multicolumn{2}{|c|}{ L.S.D at 0.05} & 0.52 & 0.36 & 0.21 & 0.38 & 0.93 & 1.04 & 2.59 & 2.76 \\
\hline \multirow{2}{*}{$\begin{array}{l}\text { Growth } \\
\text { regulator }\end{array}$} & $\mathbf{G A}_{3}$ & 23.15 & 7.89 & 11.85 & 17.79 & 23.90 & 12.83 & 12.83 & 26.94 \\
\hline & IBA & 21.30 & 6.27 & 9.94 & 15.84 & 21.15 & 10.39 & 10.33 & 22.67 \\
\hline \multicolumn{2}{|c|}{ L.S.D at 0.05} & 0.31 & 0.23 & 0.86 & 0.69 & 0.94 & 1.13 & 0.91 & 1.42 \\
\hline \multirow{3}{*}{$\begin{array}{l}\text { Concentration } \\
\text { of growth } \\
\text { regulator }\end{array}$} & 0 ppm & 19.25 & 5.99 & 8.90 & 13.75 & 17.89 & 9.25 & 9.92 & 20.17 \\
\hline & $250 \mathrm{ppm}$ & 23.47 & 7.45 & 9.83 & 16.78 & 19.03 & 10.33 & 11.08 & 25.17 \\
\hline & $500 \mathrm{ppm}$ & 26.95 & 8.82 & 11.95 & 19.92 & 26.15 & 13.25 & 13.75 & 29.08 \\
\hline \multicolumn{2}{|c|}{$\begin{array}{l}\text { L.S.D at } 0.05 \\
\end{array}$} & 0.34 & 0.41 & 0.53 & 1.14 & 3.32 & 0.79 & 1.06 & 1.88 \\
\hline
\end{tabular}

corresponding obtained increase percentages were 41.2 and $43.6 \%$ for the two seasons in the same order. These results disagree with the findings reported by Reda (1990) who suggested that, using $\mathrm{GA}_{3}$ at any adopted concentration reduced significantly the average number of branches per pea plant.

\subsubsection{The interaction between the number of prays and the used growth regulator}

The effect of the interaction between the number of sprays and growth regulator type on branch number/plant was significant in both seasons and all cuts (Table $2 \mathrm{~b}$ ). In the $1^{\text {st }}$ season, the highest value (26.52 branch/ plant) was recorded on plants received two $\mathrm{GA}_{3}$ sprays. While in the $2^{\text {nd }}$ season the highest value (29.00 branch/ plant) of the number of branches per plant was recorded with the number of branches per plant by increasing the number of applications.

3.2.2.1. Effect of the interaction between the number of sprays and the concentration of growth regulator

It is obvious that, regardless of the used type of growth regulators, applying growth regulator at 500 ppm concentration gave the highest number of branches per plant with either one or two sprays (Table $2 \mathrm{c}$ ). The first and the last cuts showed the highest number of branches per plant when received a double spray at $500 \mathrm{ppm}$ concentration being 27.05 and 31.67 branch/ plant, respectively. Relative to the control and over the four cuttings, in the case of single spray by $250 \mathrm{ppm}$, the average increased percentages in number of branches were, 20.5 and $15.7 \%$, for the $1^{s t}$ and $2^{\text {nd }}$ seasons, respectively.

Table ( 2 b): Effect of interaction between the number of sprays and growth regulators on the number of branches / stevia plant in 2007-08 and 2008-09 seasons.

\begin{tabular}{|c|c|c|c|c|c|c|c|c|c|}
\hline \multicolumn{2}{|c|}{ Treatments } & \multicolumn{4}{|c|}{ 2007-08 } & \multicolumn{4}{|c|}{ 2008-09 } \\
\hline $\begin{array}{c}\text { Number of } \\
\text { sprays }\end{array}$ & $\begin{array}{l}\text { Growth } \\
\text { regulator }\end{array}$ & $1^{s t} \mathrm{cut}$ & $2^{\text {nd }}$ cut & $3^{\text {rd }}$ cut & $4^{\text {th }}$ cut & $1^{s t}$ cut & $2^{\text {nd }}$ cut & $3^{\text {rd }}$ cut & $4^{\text {th }}$ cut \\
\hline \multirow{2}{*}{ One spray } & $\mathbf{G A}_{3}$ & 23.78 & 7.73 & 9.86 & 18.41 & 21.64 & 9.56 & 11.50 & 25.33 \\
\hline & IBA & 20.63 & 5.71 & 9.52 & 15.95 & 19.69 & 8.11 & 9.44 & 21.22 \\
\hline \multirow{2}{*}{ Two sprays } & $\mathbf{G A}_{3}$ & 26.52 & 9.06 & 11.83 & 19.17 & 24.11 & 12.11 & 14.44 & 29.00 \\
\hline & IBA & 21.96 & 6.83 & 10.36 & 15.74 & 20.66 & 10.67 & 11.22 & 24.67 \\
\hline \multicolumn{2}{|c|}{ L.S.D at 0.05} & 0.64 & 0.58 & 0.36 & $\begin{array}{l}0.31 \\
\end{array}$ & 0.69 & $\begin{array}{l}0.28 \\
\end{array}$ & 0.21 & 0.65 \\
\hline
\end{tabular}

plants received two $\mathrm{GA}_{3}$ sprays, in the $4^{\text {th }}$ cut. Generally, double sprays by $\mathrm{GA}_{3}$ treatments were likely more effective in enhancing the number of branches per plant as compared with those treated by IBA. This was further enhanced by increasing the number of sprays. The results indicated that $\mathrm{GA}_{3}$ application had more important role on increasing
However, in the case of single spray by $500 \mathrm{ppm}$, the values were 39.8 and $31.2 \%$ for the same seasons in the same order. The magnitude of this interaction was nearly doubled when two sprays were applied. Moreover, double applications by 500 $\mathrm{ppm}$ resulted in increases in the number of ppm resulted in increases in the number of branches/plant 
by 52.8 and $47.0 \%$.

3.2.2.2. Effect of the interaction between growth regulator type and the used concentrations.

As shown in Table ( $2 \mathrm{~d}$ ), and regardless of the number of applications, $\mathrm{GA}_{3}$ treatments with 500 ppm concentration produced the highest number of branches per plant. Moreover, the first and the last cuts resulted in relatively the highest number of branches per plant. The two growth regulators $\mathrm{GA}_{3}$ and IBA showed significant effect in the average
Triple interaction was used for assigning the best combination of the three studied factors that affected the average number of branches per plant. Data presented in Table ( 2 e) prove the significant effect of the interaction between the experimental three factors in both seasons and all cuts. Relative to the control, plants that received two sprays of $\mathrm{GA}_{3}$ at $500 \mathrm{ppm}$ showed the highest number of branches, being 26.89 as compared with 20.89 for the control in the $1^{\text {st }}$ season $\left(1^{\text {st }}\right.$ cut $)$. The corresponding recorded values in the second season, were 31.00

Table $(2$ c): Effect of interaction between the number of sprays and adopted concentration on the number of branches / stevia plant in 2007-08 and 2008-09 seasons.

\begin{tabular}{|c|c|c|c|c|c|c|c|c|c|}
\hline \multicolumn{2}{|c|}{ Treatments } & \multicolumn{4}{|c|}{ 2007-08 } & \multicolumn{4}{|c|}{ 2008-09 } \\
\hline $\begin{array}{c}\text { Number of } \\
\text { sprays }\end{array}$ & Concentration & $1^{s t}$ cut & $2^{n d}$ cut & $3^{r d}$ cut & $4^{\text {th }}$ cut & $1^{s t}$ cut & $2^{n d}$ cut & $3^{r d}$ cut & $4^{\text {th }}$ cut \\
\hline \multirow{3}{*}{ One spray } & 0 ppm & 17.61 & 6.22 & 8.11 & 14.92 & 16.03 & 7.50 & 8.83 & 22.00 \\
\hline & $250 \mathrm{ppm}$ & 23.39 & 6.73 & 9.64 & 16.73 & 17.42 & 9.00 & 9.83 & 26.67 \\
\hline & $500 \mathrm{ppm}$ & 26.11 & 8.21 & 11.32 & 19.90 & 26.25 & 11.50 & 12.33 & 28.50 \\
\hline \multirow{3}{*}{ Two sprays } & 0 ppm & 18.89 & 5.75 & 9.69 & 12.58 & 18.75 & 9.00 & 9.00 & 20.33 \\
\hline & $250 \mathrm{ppm}$ & 23.56 & 8.17 & 10.01 & 16.83 & 20.65 & 11.67 & 12.33 & 23.67 \\
\hline & $500 \mathrm{ppm}$ & 28.78 & 10.42 & 12.59 & 19.94 & 27.05 & 14.00 & 15.17 & 31.67 \\
\hline \multicolumn{2}{|c|}{ L.S.D at 0.05} & 0.48 & 0.59 & 0.76 & 0.66 & 0.45 & 0.50 & 0.38 & 0.46 \\
\hline
\end{tabular}

number of branches plant at any used concentration. The average increased percentage in such trait due to $500 \mathrm{ppm} \mathrm{GA}_{3}$ treatment as compared with 500 ppm IBA treatment were, 15.64 and $13.40 \%$, for the first and second seasons, respectively. These results reveal the dominant role of growth regulator type with the used concentration on the number of and 19.00 branches per plant in the $4^{\text {th }}$ cut.

Generally and regardless of the cuttings and relative to the control, two sprays of $\mathrm{GA}_{3}$ at 500 $\mathrm{ppm}$ caused increases in the average number of branches per plant ranged between 42.12 to $64.75 \%$ for the $1^{s t}$ and $2^{\text {nd }}$ seasons, respectively. It is obvious from Table $(2$ e) that, in both seasons, the control

Table ( $2 \mathrm{~d}$ ): Effect of interaction between growth regulators and the adopted concentration on number of branches / stevia plant in 2007-08 and 2008-09 seasons.

\begin{tabular}{|c|c|c|c|c|c|c|c|c|c|}
\hline \multicolumn{2}{|c|}{ Treatments } & \multicolumn{4}{|c|}{ 2007-08 } & \multicolumn{4}{|c|}{ 2008-09 } \\
\hline $\begin{array}{l}\text { Growth } \\
\text { regulator }\end{array}$ & Concentration & $\mathbf{1}^{\text {st }}$ cut & $2^{\text {nd }}$ cut & $3^{r d}$ cut & $4^{\text {th }}$ cut & $\mathbf{1}^{\text {st }}$ cut & $2^{n d}$ cut & $3^{r d}$ cut & $4^{\text {th }}$ cut \\
\hline \multirow{3}{*}{$\mathbf{G A}_{3}$} & 0 ppm & 21.78 & 6.67 & 8.68 & 13.42 & 18.12 & 9.50 & 9.33 & 21.00 \\
\hline & $250 \mathrm{ppm}$ & 23.67 & 8.34 & 9.76 & 15.89 & 22.25 & 11.00 & 10.33 & 23.83 \\
\hline & 500 ppm & 26.00 & 10.67 & 12.10 & 21.62 & 26.33 & 12.00 & 16.17 & 31.83 \\
\hline \multirow{2}{*}{ IBA } & 0 ppm & 19.72 & 5.30 & 9.11 & 14.08 & 17.67 & 9.00 & 10.50 & 22.50 \\
\hline & $500 \mathrm{ppm}$ & 23.89 & 7.96 & 10.81 & 18.23 & 25.97 & 12.50 & 11.83 & 26.33 \\
\hline \multicolumn{2}{|c|}{ L.S.D at 0.05} & 0.48 & 1.42 & 0.50 & 1.48 & 0.57 & 0.61 & 1.24 & 2.71 \\
\hline
\end{tabular}

branches per plant since 500 ppm concentration always produces the highest number of branches / plant.

3.2.2.3. Effect of the interaction between the number of sprays, type of growth regulator and the used concentration exhibited less number of branch/ plant comparing with the treated plants. Moreover, the plants treated with $\mathrm{GA}_{3}$ were more branched than those treated with IBA at the same concentration.

\subsection{Total yield of dry leaves per plant (g)}

3.3.1. The main effects

3.3.1.1. Number of sprays 
Table ( 2 e): Effect of interaction between the number of sprays, growth regulators and the adopted concentrations on the number of branches per stevia plant in 2007-08 and 2008-09 seasons.

\begin{tabular}{|c|c|c|c|c|c|c|c|c|c|c|}
\hline \multicolumn{3}{|c|}{ Treatments } & \multicolumn{4}{|c|}{ 2007-08 } & \multicolumn{4}{|c|}{ 2008-09 } \\
\hline $\begin{array}{l}\text { Number } \\
\text { of sprays }\end{array}$ & $\begin{array}{l}\text { Growth } \\
\text { regulator }\end{array}$ & Concentration & $1^{\text {st }}$ cut & $2^{\text {nd }}$ cut & $3^{r d}$ cut & $4^{\text {th }}$ cut & $1^{\text {st }}$ cut & $2^{\text {nd }}$ cut & $3^{r d}$ cut & $4^{\text {th }}$ cut \\
\hline \multirow{6}{*}{ One spray } & \multirow{3}{*}{$\mathbf{G A}_{3}$} & 0 ppm & 20.67 & 7.33 & 8.00 & 14.33 & 15.07 & 8.33 & 8.67 & 21.67 \\
\hline & & 250 ppm & 23.55 & 7.68 & 9.61 & 16.28 & 14.67 & 10.00 & 9.33 & 25.00 \\
\hline & & 500 ppm & 26.50 & 8.17 & 10.94 & 20.67 & 27.17 & 12.67 & 14.33 & 29.67 \\
\hline & \multirow{3}{*}{ IBA } & 0 ppm & 17.55 & 5.11 & 8.22 & 15.50 & 17.00 & 6.67 & 9.00 & 23.33 \\
\hline & & 250 ppm & 23.22 & 5.78 & 9.68 & 17.18 & 20.17 & 8.00 & 10.33 & 28.33 \\
\hline & & $500 \mathrm{ppm}$ & 23.67 & 6.25 & 10.68 & 17.23 & 24.77 & 10.33 & 10.57 & 30.67 \\
\hline \multirow{6}{*}{$\begin{array}{l}\text { Two } \\
\text { sprays }\end{array}$} & \multirow{3}{*}{$\mathbf{G A}_{3}$} & 0 ppm & 20.89 & 6.00 & 9.37 & 13.50 & 21.17 & 10.67 & 10.00 & 19.00 \\
\hline & & $250 \mathrm{ppm}$ & 23.78 & 9.00 & 9.90 & 16.50 & 21.83 & 12.00 & 11.33 & 22.67 \\
\hline & & $500 \mathrm{ppm}$ & 26.89 & 11.18 & 11.97 & 22.57 & 29.33 & 13.67 & 18.00 & 31.00 \\
\hline & \multirow{3}{*}{ IBA } & 0 ppm & 18.89 & 5.50 & 9.01 & 13.67 & 18.33 & 11.33 & 12.00 & 18.67 \\
\hline & & $250 \mathrm{ppm}$ & 23.33 & 7.33 & 10.12 & 18.17 & 19.47 & 11.33 & 13.33 & 24.67 \\
\hline & & $500 \mathrm{ppm}$ & 26.11 & 9.67 & 10.23 & 19.22 & 23.33 & 12.33 & 14.50 & 26.33 \\
\hline \multicolumn{3}{|c|}{ L.S.D. 0.05} & 0.68 & 1.92 & 0.57 & 0.85 & 3.61 & 1.58 & 1.37 & 1.83 \\
\hline
\end{tabular}

Data presented in Table (3 a) prove that, applying two sprays always resulted in high yield as compared with one spray, being 9.54 and $10.94 \%$ increases in the yield of dry leaves per plant in both seasons. It is worthy to mention that the control plants that received tap water showed low yield of dry leaves as compared with the plants received either one or two sprays of growth regulators.

\subsubsection{Type of growth regulator}

Data presented in Table ( 3 a) indicate that, in both seasons, $\mathrm{GA}_{3}$ treatments yielded the highest dry leaves per plant compared with IBA treatments. leaves as compared with the untreated controls, indicating the advantage of growth regulator treatments on the yield of dry leaves of stevia plant.

\subsubsection{Adopted concentration}

Statistically, significant differences in the yield were detected between the three used concentrations; 0, 250 and $500 \mathrm{ppm}$ (Table 3 a). However, the control showed the lowest yield of dry leaves as compared with the treated plants. It is clear that the highest used dose $500 \mathrm{ppm}$ provided prominent effect on the average of this trait. Relative to the control, the average increased

Table ( 3 a): Effect of the number of sprays, growth regulators and the adopted concentration on the total yield of leaves dry weight/ plant of stevia plant in 2007-08 and 2008-09 seasons.

\begin{tabular}{|c|c|c|c|}
\hline \multicolumn{2}{|c|}{ Treatments } & 2007-08 & 2008-09 \\
\hline \multirow{2}{*}{ Number of spray } & One spray & 90.39 & 88.37 \\
\hline & Two sprays & 99.01 & 98.04 \\
\hline \multicolumn{2}{|l|}{ L.S.D at 0.05} & 3.01 & 6.69 \\
\hline \multirow{2}{*}{ Growth regulator } & $\mathbf{G A}_{3}$ & 101.97 & 102.97 \\
\hline & IBA & 83.43 & 84.25 \\
\hline \multicolumn{2}{|l|}{ L.S.D at 0.05} & 4.80 & 6.20 \\
\hline \multirow{3}{*}{ Concentration of growth regulator } & O ppm & 78.42 & 79.81 \\
\hline & $250 \mathrm{ppm}$ & 94.94 & 93.76 \\
\hline & 500 ppm & 104.74 & 106.06 \\
\hline \multicolumn{2}{|l|}{ L.S.D at 0.05} & 2.63 & 4.33 \\
\hline
\end{tabular}

The average increases in leaves dry weight due to $\mathrm{GA}_{3}$ treatments, as compared with IBA treatments, were 22.22 and $22.21 \%$ for the $1^{\text {st }}$ and $2^{\text {nd }}$ seasons, respectively. It is worthy to mention that both used growth regulator type showed high yield of dry percentages due to $500 \mathrm{ppm}$ treatments were 33.56 and $32.89 \%$ for the $1^{\text {st }}$ and the $2^{\text {nd }}$ seasons, respectively. The other used concentration (250 ppm) showed similar effects with relatively low magnitude. 
It is also noticed previously by many workers that $\mathrm{GA}_{3}$ treatment generally enhanced relative leaf area growth rate (LAGR). Since, LAGR, with some exceptions, increased with the rate of foliar $\mathrm{GA}_{3}$ treatment in stevia plant. It is also reported that foliar spray with $100 \mathrm{ppm} \mathrm{GA}_{3}$ showed the highest values for plant height, number of branches and leaves, leaf area and dry matter in soybean plant (Deotale et al.1998). Leite et al. (2003) found that applying gibberellin increased leaf area in soybean. In addition, IBA is a synthetic auxin and is used commercially for enhancing crop production and regulation of plant growth and development of rapid growth such as shoot tissue, young leaves elongation and promotion of lateral root development (Nagel et al., 2001).

\subsubsection{The interaction between the number of} sprays and growth regulator type

Data presented in Table $(3 \mathrm{~b})$ show the interaction effects between the used number of sprays and the types of the applied growth regulator. Significant differences were detected between the two studied factors. Generally, in both seasons, double sprays of $\mathrm{GA}_{3}$ treatments produced the highest yield of dry leaves (97.41 and 99.90 g.) for $1^{s t}$ and $2^{\text {nd }}$ seasons, respectively. In the case of IBA treatments, the plants received double IBA applications recorded higher yield as compared with those treated by single spray. In the first season, the

Table ( 3 b): Effect of the interaction between the number of sprays and growth regulator on total yield of leaves dry weight per stevia plant in 2007-08 and 2008-09 seasons

\begin{tabular}{|l|c|c|c|}
\hline \multicolumn{2}{|c|}{ Treatments } & \multirow{2}{*}{ 2007-08 } & $\mathbf{2 0 0 8 - 0 9}$ \\
\hline $\begin{array}{l}\text { Number } \\
\text { of spray }\end{array}$ & $\begin{array}{l}\text { Growth } \\
\text { regulator }\end{array}$ & & \\
\hline One & GA $_{3}$ & 90.38 & 95.34 \\
spray & IBA $_{n}$ & 82.02 & 86.20 \\
\cline { 2 - 2 } Two & GA $_{\mathbf{3}}$ & 97.41 & 99.90 \\
sprays & IBA & 86.60 & 89.42 \\
\hline \multicolumn{2}{|l|}{ L.S.D at 0.05 } & 4.39 & 2.10 \\
\hline
\end{tabular}

average increase percentage in the yield of dry leaves due to the double $\mathrm{GA}_{3}$ sprays as compared with single spray was $7.78 \%$. While, it was $5.58 \%$ in the case of IBA treatment. The same trend was obtained in the second season, where the increased percentages were 4.78 and $3.73 \%$ for $\mathrm{GA}_{3}$ and IBA treatments, respectively. From the above mentioned results, it is obvious that the effect of growth regulator is more dominant than the effect of the number of sprays.

\subsubsection{The interaction between the number of sprays and growth regulator concentrations}

As shown in Table (3c), regardless of the type of growth regulator, the highest concentration $500 \mathrm{ppm}$ produced the highest yield of dried leaves per plant. In both seasons the highest yield per plant was recorded on plants received double sprays of 500 ppm, being 108.49 and $112.94 \mathrm{~g}$ for the first and the second seasons, respectively.

Table ( 3 c): Effect of interaction between the number of sprays and concentrations of growth regulators on the total yield of leaves dry weight per stevia plant in 2007-08 and 2008-09 seasons.

\begin{tabular}{|l|c|c|c|}
\hline \multicolumn{2}{|c|}{ Treatments } & \multirow{2}{*}{ 2007-08 } & \multirow{2}{*}{$\mathbf{2 0 0 8 - 0 9}$} \\
\hline $\begin{array}{c}\text { Number } \\
\text { of sprays }\end{array}$ & Concentration & & \\
\hline \multirow{3}{*}{ One spray } & $\mathbf{0 ~ p p m}$ & 84.58 & 84.84 \\
\cline { 2 - 2 } & $\mathbf{2 5 0} \mathbf{~ p p m}$ & 95.59 & 91.10 \\
\cline { 2 - 2 } & $\mathbf{5 0 0} \mathbf{~ p p m}$ & 100.99 & 99.17 \\
\multirow{2}{*}{ Two } & $\mathbf{0 ~ p p m}$ & 82.25 & 84.78 \\
\cline { 2 - 2 } sprays & $\mathbf{2 5 0} \mathbf{~ p p m}$ & 95.29 & 96.42 \\
\cline { 2 - 3 } & $\mathbf{5 0 0} \mathbf{~ p p m}$ & 108.49 & 112.94 \\
\hline \multicolumn{2}{|l|}{ L.S.D at 0.05 } & 3.23 & 2.84 \\
\hline
\end{tabular}

The corresponding recorded yields due to the single spray were 100.99 and $99.17 \mathrm{~g}$. Relative to the control, the average increased percentage in the mean of this trait due to single spray by $500 \mathrm{ppm}$ were 19.40 and $16.89 \%$ in both seasons. While in case of double sprays with $500 \mathrm{ppm}$, the average increased yield percentages were 31.9 and $33.21 \%$ for the first and second seasons, respectively. Thus, it could be stated that the double spray treatment with the high concentration was apparently more effective for producing stevia high yield.

\subsubsection{The interaction between type of growth regulator and the used concentration}

It is realized that, the interaction between type of growth regulator and the used concentrations was significant. Regardless of the number of used sprays, $\mathrm{GA}_{3}$ treatments with high concentration 500 ppm caused the highest yield of dried leaves per plant (Table $3 \mathrm{~d}$ ). Same with relatively lower values in case of $250 \mathrm{ppm}$ concentration, where, $\mathrm{GA}_{3}$ treatments showed a relatively high yield as compared with IBA. 
Table (3 d): Effect of interaction between growth regulators and adopted concentration on total yield of leaves dry weight per stevia plant in 2007-08 and 2008-09 seasons.

\begin{tabular}{|l|c|c|c|}
\hline \multicolumn{2}{|c|}{ Treatments } & \multirow{2}{*}{ 2007-08 } & 2008-09 \\
\hline \multirow{2}{*}{$\begin{array}{c}\text { Growth } \\
\text { regulator }\end{array}$} & Concentration & & \\
\hline \multirow{4}{*}{ GA $_{3}$} & $\mathbf{0 ~ p p m}$ & 79.81 & 78.64 \\
& $\mathbf{2 5 0} \mathbf{~ p p m}$ & 96.54 & 95.83 \\
\cline { 2 - 2 } & $\mathbf{5 0 0} \mathbf{~ p p m}$ & 106.10 & 108.75 \\
& $\mathbf{0} \mathbf{~ p p m}$ & 77.03 & 79.98 \\
\cline { 2 - 2 } IBA & $\mathbf{2 5 0} \mathbf{~ p p m}$ & 93.34 & 91.70 \\
\cline { 2 - 2 } & $\mathbf{5 0 0} \mathbf{~ p p m}$ & 98.20 & 101.10 \\
\hline
\end{tabular}

Relative to the control, the average increased percentage in the mean of such trait due to $500 \mathrm{ppm}$ $\mathrm{GA}_{3}$ were 32.94 and $38.29 \%$ in both seasons, while 500 ppm IBA treatment increased the yield percentages by 27.00 and $26.0 \%$ for the first and second seasons, respectively. The used concentrations of $250 \mathrm{ppm}$ of $\mathrm{GA}_{3}$ or IBA showed a minute promotion in the mean of such trait.

3.3.2.3. The interaction between number of sprays, type of growth regulators and the used concentrations

The triple interactions between the investigated three experimental factors in both seasons were significant (Table 3 e). Relative to the control, in both seasons, the average yield of dry leaves showed a gradual increasing as the adopted

Table ( 3 e): Effect of interaction between number of sprays, growth regulator and the adopted concentration on total yield of leaves dry weight per stevia plant in 2007-08 and 2008-09 seasons.

\begin{tabular}{|c|c|c|c|c|}
\hline \multicolumn{3}{|c|}{ Treatments } & \multirow[t]{2}{*}{ 2007-08 } & \multirow[t]{2}{*}{ 2008-09 } \\
\hline $\begin{array}{l}\text { Number } \\
\text { of sprays }\end{array}$ & $\begin{array}{l}\text { Growth } \\
\text { regulator }\end{array}$ & Concentration & & \\
\hline \multirow{6}{*}{$\begin{array}{l}\text { One } \\
\text { spray }\end{array}$} & \multirow{3}{*}{$\mathbf{G A}_{3}$} & 0 ppm & 74.43 & 73.99 \\
\hline & & $250 \mathrm{ppm}$ & 93.32 & 90.58 \\
\hline & & $500 \mathrm{ppm}$ & 100.64 & 99.40 \\
\hline & \multirow{3}{*}{ IBA } & 0 ppm & 76.86 & 77.69 \\
\hline & & $250 \mathrm{ppm}$ & 95.21 & 88.63 \\
\hline & & $500 \mathrm{ppm}$ & 98.37 & 93.94 \\
\hline \multirow{6}{*}{$\begin{array}{l}\text { Two } \\
\text { sprays }\end{array}$} & \multirow{3}{*}{$\mathbf{G A}_{3}$} & 0 ppm & 77.31 & 75.29 \\
\hline & & $250 \mathrm{ppm}$ & 93.36 & 101.07 \\
\hline & & 500 ppm & 111.56 & 113.33 \\
\hline & \multirow{3}{*}{ IBA } & 0 ppm & 77.19 & 74.27 \\
\hline & & $250 \mathrm{ppm}$ & 97.86 & 91.77 \\
\hline & & 500 ppm & 101.41 & 98.73 \\
\hline \multicolumn{3}{|l|}{ L.S.D. 0.05} & 2.72 & 3.94 \\
\hline
\end{tabular}

concentration increased and number of sprays.

To assign the best combined treatment among the three studied factors, data proved that, double sprays by $\mathrm{GA}_{3}$ at $500 \mathrm{ppm}$ produced the highest yield 111.56 and $113.33 \mathrm{~g}$. per plant in the $1^{\text {st }}$ and $2^{\text {nd }}$ seasons, respectively. Comparing the yield of plants that received two sprays of $\mathrm{GA}_{3}$ at $500 \mathrm{ppm}$ and two sprays of IBA at the same concentration, showed an increased yield by 10.0 and $14.0 \%$ for the first and the second seasons, respectively. The corresponding increased yield percentages in case of single spray were 2.0 and $5.0 \%$ for both seasons in the same order. It is also noticed that, relative to the control, over the two seasons, the average increased percentages due to $500 \mathrm{ppm}$ concentrations were $34.5,23.5 \%$ and $47.0 \%, 30.0 \%$ for $\mathrm{GA}_{3}$ single and double sprays and IBA single and double sprays, respectively. This emphasized the tremendous effect of $\mathrm{GA}_{3}$ on the yielding ability of stevia dry leaves.

\section{REFERENCES}

Abou-Bakr M.H.A. and El-Sgai M.U.A. (2001). Effect of gibberellic acid $\left(\mathrm{GA}_{3}\right)$ on morphology, anatomy and chemical constituents of Roselle plant (Hibiscus sabdariffa L.). J. Agric. Sci., Mansoura Univ., 26 (5): 2817-2830.

Anonymous (1986). Computer software designed for statistical analysis. Version, O/Em. Copyrighted June 1982-1986. Michigan State Univ. Revised by: Dept of Crop and Soil Sci., Michigan State Univ.

Attya A.E. (2005). Effect of Some Agronomic Treatments on stevia (Stevia rebaudiana, Bertoni) Yield and Quality in Egypt. Ph. D. Thesis, Faculty of Agriculture, Department of Agronomy, Ain Shams University. 116. pp.

Basford K.H. (1961). Morphogenic response to gibberellic acid of a radiation induced mutant dwarf in groundsel, Senecio vulgaris L. Ann. Bot. (N.S.) 25: 279-303.

Bernier G., Bronchart R. and Jacomard A. (1964). Action of gibberellic acid on the mitotic activity of the different zones of the shoot apex of Rudbeckia bicolor and Perilla nankinensis. Planta 61: 236-244.

Bhattachartee A.K., Mittra B.N. and Mitra P.C. (2000). Seed agronomy of jute. 111 Production and quality of Corchorus olitorius 
L. seed as influenced by growth regulators. Seed Science and Technology. 28:2, 421-436.

David J. M. and A. H. Rank (2002). A report for the Rural Industries Research and Development Corporation. August.RIRDC Web Publication No W02/022. RIRDC Project No UCQ-16A.

Deotale R.D., Maske V.G., Sorte N.V., Chimurkar B.S. and Terne A.Z. (1998). Effect of $\mathrm{GA}_{3}$ and NAA on morpho-physiological parameters of soybean. Journal of Soils and Crops, 8(1): 91-94.

Ebad F.A., Ezzat N.H., Ouda A.M. and El-Gaaly F.M. (1990). Effect of gibberellic acid on growth and some metabolic products in sunflower and maize plants grown under different saline conditions. Desert Inst. Bull., A.R.E., 40(1): 119-140.

El-Shaarawi A. I., Fouad M.K., El-Sahhar K.F. and El-Sherbeny S.S (1982). Effect of gibberellic acid $\left(\mathrm{GA}_{3}\right)$ and nitrogen fertilization on the growth of Hibiscus sabdariffa L. Research Bulletin No. 1926, Ain-Shams Univ. 30 pp.

Leite M.V., Rosolem C.A. and Rodrigues D. (2003). Gibberelin and cytokinin effects on soybean growth, Sci. Agric., 60(3): 537-541

Loy J.B. and Liu P.B.W. (1974). Response of seedlings of a normal and dwarf strain of watermelon to gibberellins. Plant Physiol. 53: 325-330.
Ludwig-Muller J. (2000). Indole-3-butyric acid in plant growth and development. J. Plant Growth Regul. 32: 219-230.

Ludwig-Muller J., Sass S., Sutter E., Wodner M and Epstein E. (1993). Indole-3-butyric acid in Arabidopsis thaliana. J Plant Growth Regul 13: 179-187.

Mander L.N. (2003). Twenty years of gibberellin research. Nat. Prod. Rep. 20, 49-69.

Nagel L. R. Brewster, Riedell W. E. and Reese R. N. (2001). Cytokinin regulation of flower and pod set in soybeans (Glycine $\max (\mathrm{L}$.) Merr.) . Annals of Botany 88: 27-31.

Reda F.M. (1990). Effect of Some Growth Regulators on Morphological and Histological Characteristics of Pea Plant (Pisum sativum L.). M.Sc. Thesis, Fac. Agric., Cairo Univ., 169p.

Sachs R.M. and Kofranek A.M. (1963). Comparative cytohistological studies on inhibition and promotion of stem growth in Chrysanthemum morifolium. Amer. J. Bot. 50: 772-779.

Sakr R.A. and El-Kady M.A. (1981). Effect of cycocel and gibberellins on faba bean (Vicia faba L.) plants. 1- Vegetative and anatomical traits. Res. Bull., Fac. Agric., Zagazig Univ., No. 427. $18 \mathrm{pp}$.

Yamagishi J. (1992). Effects of gibberellic acid application on panicle characters and size of shoot apex in the first bract differentiation stage in Rice. Plant Prod. Sci. 4(3): 227-229.

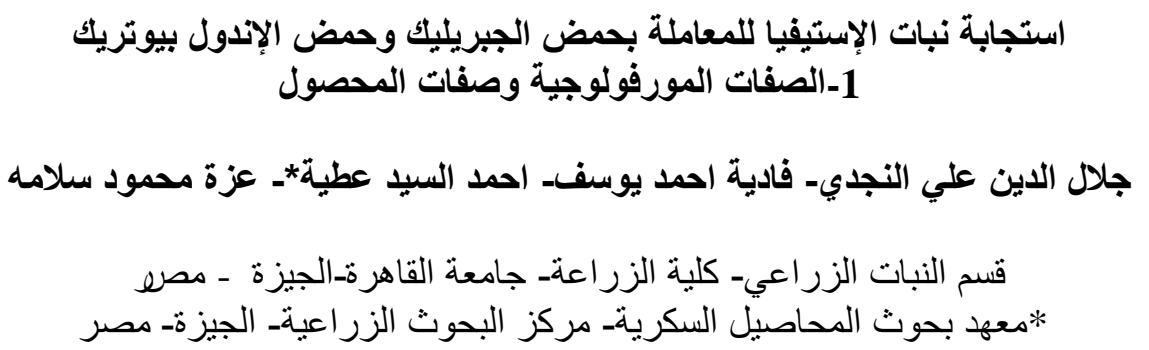

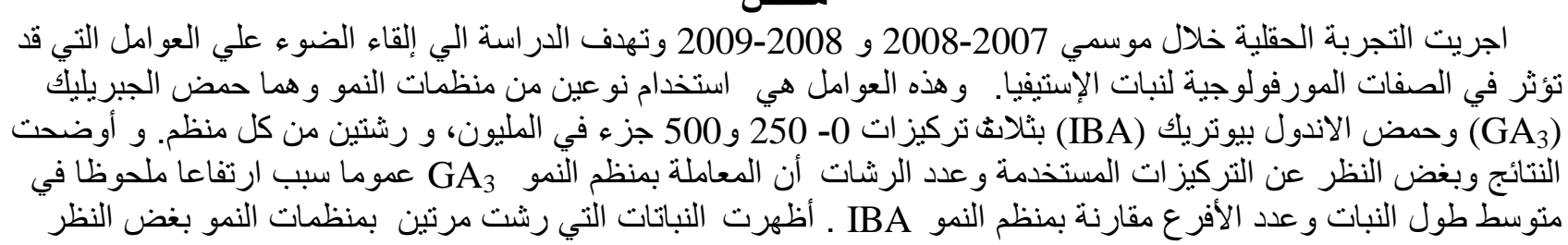




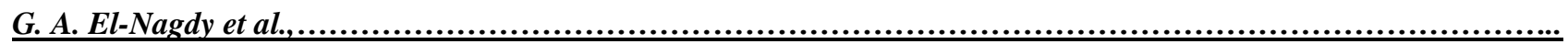

عن نوعه او التركيز المستخدم اظهرت ارتفاعا ملحوظا في طول و عدد الأفرع. كذلك أمكن ايجاد علاقة ايجابية بين منوسطات

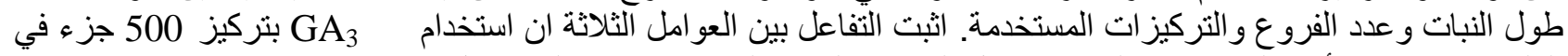

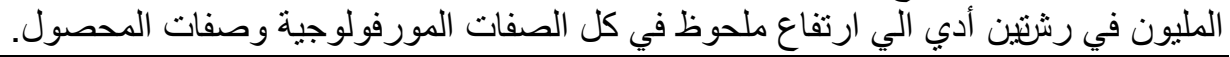

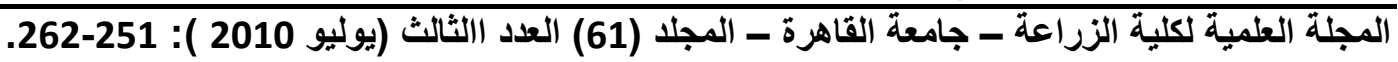

